\title{
Wokół podziałów administracyjnych Wrocławia i dyskusji nad reformą rad osiedlowych
}

\#dzielnice \#rady osiedli, \#jednostki pomocnicze \#podział administracyjny \#ustrój miasta \#samorzą terytorialny \#miasto \#wybory \#decentralizacja \#districts \#housing estate councils \#auxiliary units \#administrative division \#city's form of government \#local government, \#city \#elections \#decentralization

Do 1991 r. Wrocław podzielony był administracyjnie na pięć dzielnic. Wraz z odbudową instytucji samorządu terytorialnego w Polsce po 1989 r., nowe władze samorządowe miasta w miejsce dzielnic wprowadziły podział na jednostki pomocnicze w formie osiedli z wybieralnymi radami. Niestety nie wyposażono ich w odpowiednie zadania i kompetencje, w tym finanse, mimo podejmowanych na ten temat dyskusji i prób reformy wewnętrznego ustroju miasta. Niska frekwencja wyborcza w wyborach do rad osiedli świadczy o słabości tych rad i potrzebie zmiany ich pozycji oraz rangi przez Radę Miejską Wrocławia. Jest to warunek skutecznego i dobrego zarządzania sprawami lokalnymi w mikroskali, tj. na terenie osiedla.

Until 1991, Wrocław was divided into five administrative districts. Along with the reconstruction of the local self-government institutions in Poland after 1989, the new local government authorities replaced these districts with the division into auxiliary units in the form of housing estates with elected councils. Unfortunately, no appropriate competences and tasks were assigned to them, including finances, despite ongoing discussions and attempts to reform the city's form of government. Low voter turnout in the elections to housing estate councils indicates the weakness of these councils and the need to change their position and rank by Wrocław City Council. This is a prerequisite for the effective and good management of local matters on a micro scale, i.e. within a housing estate.

Miasto. Pamięć i Przyszłość 1 (2017) ISSN 2543-621X

\section{OPEN ACCESS}

Citation: Czapiewski E., Nowakowski R., Around the administrative divisions and the debate on the reform of community councils, „Miasto. Pamięć i Przyszłość: Wrocławski Rocznik Samorządowy" - No 1 https://doi.org/10.xxxxx

Editor: Katarzyna Uczkiewicz Received: October, 2016 Accepted: December, 2016

Published: December, 2016

Copyright: @ Ośrodek „Pamięć i Przyszłość" This is an open access article distributed under the terms of the Creative Commons Attribution-ShareAlike Licence, which permits unrestricted use, distribution, and reproduction in any medium, provided the original author and source are credited, with indications if any changes are made. All derivative works must be licensed under the same licence.

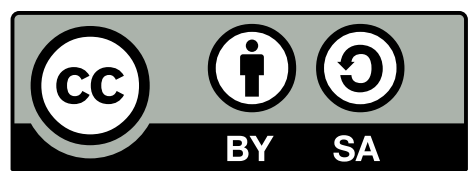




\section{Wokół podziałów administracyjnych Wrocławia i dyskusji nad reformą rad osiedlowych}

\section{Wstęp}

Dwudziestego marca 1991 r. na XX sesji Rada Miejska Wrocławia dokonała podziału miasta na 47 pomocniczych jednostek samorządowych w formie osiedli. Tym sposobem zlikwidowano model zarządzania miastem w oparciu o dzielnice, który utrzymał się w mieście przez prawie cztery dekady. Nowe rozwiązanie okazało się trwałe. Jednak spory i dyskusje wokół funkcjonowania, w tym potrzeby dalszej reformy, rad osiedli są wciąż tematem dyskursu zarówno w łonie samych władz miejskich, jak i podmiotów działających w przestrzeni miejskiej. Impulsem do dyskusji jest nie tylko dotychczasowa ocena działania rad osiedlowych, ich umocowanie w strukturze administracyjnej miasta czy też realna możliwość działania w ramach przekazanych prerogatyw i finansów, ale także przykład innych gmin,m m.in. Poznania, którego władze ostatnio przebudowały wewnętrzny podział administracyjny. Nie dziwi więc fakt, iż w obecnej VII kadencji Rady Miejskiej Wrocławia temat działania i reformowania jednostek pomocniczych w formie osiedli jest istotnym przedmiotem analizy i prac komisji Rady Miejskiej. Niniejszy tekst jest nie tylko pretekstem do przypomnienia dotychczasowych podziałów Wrocławia, prób i koncepcji reformowania jednostek pomocniczych na przestrzeni ostatniego ćwierćwiecza. Jest przede wszystkim przyczynkiem do dyskusji na temat roli i przyszłości rad osiedlowych w systemie zarządzania stolicą regionu.

\section{Wrocław dzielnicowy}

W okresie 1952-1991 Wrocław funkcjonował w tzw. rozbiciu dzielnicowym. W lutym 1952 r. w miejsce 8 komisariatów obwodowych, które funkcjonowały w tej liczbie od 1946 r. (pierwotnie 12), utworzono 5 dzielnic: Fabryczna, Krzyki, Stare Miasto, Śródmieście i Psie Pole. Już pięć lat później nastąpiła zasadnicza zmiana w umocowaniu dzielnic, co było konsekwencją zmiany statusu Wrocławia. Dekretem Rady Państwa z 31 grudnia 1956 r. 400-tysięczny Wrocław wraz z Krakowem i Poznaniem został wyłączony z województwa, a Miejskiej Radzie 
Narodowej we Wrocławiu nadano uprawnienia wojewódzkiej rady narodowej¹. Z dniem 1 stycznia 1957 r. Miejską Radę Narodową we Wrocławiu przemianowano na Radę Narodową miasta Wrocławia (RNmW). Decyzja władz centralnych, mocno wspierana przez władze miejskie, oznaczała zmianę jakościową w życiu miasta, w tym samych dzielnic. Z pozycji wnioskodawczej i opiniodawczej awansowały do roli gospodarza na własnym terenie, z własnymi budżetami, kompetencjami finansowymi, aparatem administracyjnym i zadaniami m.in. w zakresie planistycznym, szkolnictwa podstawowego wraz z nadzorem pedagogicznym, wychowania przedszkolnego etc. Zmiany wywołane nowym statusem miasta zmieniły nie tylko model zarządzania miastem, w którym zarówno władze miejskie, jak i dzielnicowe otrzymały szereg nowych uprawnień, ale przyczyniły się do jakościowej zmiany w sferze organizowania, planowania i wykonywania zadań2. W każdej dzielnicy mieszkańcy wybierali własne organy uchwałodawcze, tj. rady dzielnicowe, a te z kolei wyłaniały organ wykonawczo-zarządzający w postaci Prezydium Rady Dzielnicy z przewodniczącym na czele. Ten zawiadywał z kolei całym dzielnicowym aparatem wykonawczym składającym się z wydziałów, prezydium, któremu podlegały m.in. dzielnicowe przedsiębiorstwa remontowo-budowlane,

1. Dekret Rady Państwa z dnia 31 XII 1956 r. o wyłączeniu z województw miast: Krakowa, Poznania i Wrocławia oraz nadaniu miejskim radom narodowym tych miast uprawnień wojewódzkich rad narodowych (Dz. U. 1957, Nr 1, poz. 1).

2. R. Nowakowski, Jak w PRL zabiegano o zmianę rangi i pozycji administracyjnej Wrocławia, Kwartalnik „Pamięć i Przyszłośćc, nr 31 (1/16), s. 61.

3. Rozwój terytorialny, [w:] Encyklopedia Wrocławia, red. J. Harasimowicz, Wrocław 2006, s. 757-758.

4. Ustawa z dnia 20 marca 1950 r. o terenowych organach jednolitej władzy państwowej (Dz. U. 1950, Nr 18, poz. 17). budynki i mieszkania będące w zarządzie Dzielnicowych Zarządów Budynków Mieszkalnych (DZBM), pozostałe instytucje i zakłady, sprawy społeczne, gospodarcze, kulturalne etc.

W wyniku nadania miastu statusu "miasta wyłączonego" władze miejskie uzyskały w postępowaniu administracyjnym status II instancji, podczas gdy władze dzielnicy - I instancji. Warto wspomnieć o próbie utworzenia na początku 1957 r. trzech dodatkowych dzielnic dla osiedli Brochów, Psie Pole oraz Leśnica. Mimo oddolnych nacisków mieszkańców tych osiedli RNmW wypowiedziała się negatywnie w tej sprawie i dokonała korekty granic administracyjnych miasta poprzez włączenie tych osiedli w obszar dotychczasowych pięciu dzielnic. Nie była to jedyna zmiana granic administracyjnych Wrocławia. W 1951 r. do miasta włączono miejscowości w większości zurbanizowane i silnie powiązane z nim funkcjonalnie: Bieńkowice, Brochów, Jagodno, Klecinę, Lamowice Stare, Miłostów, Muchobór Wielki, Oporów, Ołtaszyn, Wojnów, Wojszyce, Zakrzów, Zgorzelisko. Następnie w latach 1970 i 1973 r. w granice Wrocławia włączono zachodnie i północne tereny, tj. Strachowic, Osińca, Jerzmanowa, Jarnołtowa, Żar, Mokrej, Marszowic, Rędzina, Świniar, Widawy, Polanowic, Praczy Widawskich, Lipy Piotrowskiej, Kłokoczyc i Pawłowic. Tym sposobem powierzchnia Wrocławia w 1973 r. sięgnęła 292,8 km², podczas gdy w 1951 r. 225,0 km² (przed wojną 175,1 km² - stan na 1928 r.) $)^{3}$.

System rad narodowych, który obowiązywał w latach 1950-1990, wprowadzony został ustawą z 20 marca 1950 r.4. Pierwsze wybory do rad

Miasto. Pamięć i Przyszłość 1 (2016) ISSN 2543-621X 
Tab. 1. Liczba mandatów przypadająca na rady dzielnicowe w danej kadencji

\begin{tabular}{|c|c|c|c|c|c|c|}
\hline \multirow{2}{*}{\begin{tabular}{c}
\multirow{2}{*}{$\begin{array}{c}\text { Rok } \\
\text { wyborczy }\end{array}$} \\
\multirow{2}{*}{ Ogółem }
\end{tabular}} & \multicolumn{5}{|c|}{$\begin{array}{c}\text { Liczba mandatów do poszczególnych Dzielnicowych } \\
\text { Rad Narodowych m. Wrocławia (DRNm.W) }\end{array}$} \\
\cline { 3 - 7 } & & $\begin{array}{c}\text { DRN } \\
\text { Stare Miasto }\end{array}$ & $\begin{array}{c}\text { DRN } \\
\text { Śródmieście }\end{array}$ & $\begin{array}{c}\text { DRN } \\
\text { Krzyki }\end{array}$ & $\begin{array}{c}\text { DRN } \\
\text { Fabryczna }\end{array}$ & $\begin{array}{c}\text { DRN } \\
\text { Psie Pole }\end{array}$ \\
\hline 1954 & 475 & 75 & 125 & 100 & 100 & 75 \\
\hline 1958 & 270 & 50 & 70 & 50 & 50 & 50 \\
\hline 1961 & 270 & 50 & 70 & 50 & 50 & 50 \\
\hline 1965 & 320 & 50 & 70 & 70 & 70 & 60 \\
\hline 1969 & 360 & 65 & 80 & 80 & 75 & 60 \\
\hline 1973 & 440 & 80 & 95 & 100 & 90 & 75 \\
\hline 1978 & 450 & 80 & 100 & 100 & 95 & 75 \\
\hline 1984 & 460 & 80 & 100 & 100 & 100 & 80 \\
\hline 1988 & 400 & 80 & 80 & 80 & 80 & 80 \\
\hline Razem & 3445 & 610 & 790 & 730 & 710 & 605 \\
\hline
\end{tabular}

Źródło: Zestawienie i obliczenia własne na podstawie Obwieszczeń Komisarzy Wyborczych o wynikach wyborów do poszczególnych rad narodowych $\mathrm{m}$. Wrocławia za lata 1954-1988.

narodowych wszystkich szczebli, w tym dzielnicowych, odbyły się dopiero 5 grudnia 1954 r. Wynikało to z faktu, że ustawa z 11 września 1944 r. o organizacji i zakresie działania rad narodowych nie przewidywała w początkowym okresie wyłaniania członków rad narodowych w drodze wyborów, lecz w oparciu o system delegowania i dokooptowania radnych ${ }^{5}$. Ordynacja wyborcza do rad narodowych uchwaIona została wczesną jesienią 1954 r. ${ }^{6}$, a więc dopiero po uchwaleniu konstytucji PRL z lipca 1952 r. Ostatnie wybory do rad narodowych przeprowadzono 19 czerwca 1988 r. W związku z zainicjowaniem na przełomie 1989 i 1990 r.

Miasto. Pamięć i Przyszłość 1 (2016) ISSN 2543-621X reformy samorządowej ostatnia kadencja rad narodowych trwała tylko dwa lata. Przez okres czterech dekad rady narodowe, w tym dzielnicowe, były organami władzy państwowej. Obok instancji partyjnych w terenie były najważniejszą strukturą administrującą i zarządzającą daną jednostką administracyjną, tj. dzielnicą, miastem, województwem. Obecność w tych gremiach wiązała się z szeregiem profitów i przywilejów zarezerwowanych wyłącznie dla tej grupy działaczy partyjnych tworzących ówczesną elitę polityczną w terenie. Wielu działaczy dzielnicowych kontynuowało "karierę" na szczeblu miejskim czy wojewódzkim, np. Andrzej Kosowski - naczelnik 
dzielnicy Wrocław Śródmieście - został wiceprezydentem Wrocławia w 1984 r., podobnie jak Stefan Skąpski - dyrektor Wydziału Zatrudnienia i Spraw Socjalnych Urzędu Wojewódzkiego we Wrocławiu ${ }^{7}$. Nie brakło takich, którzy również po 1990 r. pełnili ważne funkcje publiczne, np. Jerzy Ratajski, naczelnik dzielnicy Stare Miasto, a później sekretarz miasta.

Wybory do dzielnicowych rad narodowych Wrocławia odbywały się nierzadko jednocześnie z wyborami do rady narodowej dla miasta Wrocławia. W latach 1954-1990 w dzielnicowych radach narodowych zasiadało łącznie 3445 radnych, z tego 852 (tj. 24,7\%) stanowiły kobiety8.

W ramach każdej dzielnicy funkcjonowały komitety blokowe i osiedlowe. Samoorganizacja mieszkańców formowała się początkowo w sposób spontaniczny. Od połowy lat sześćdziesiątych XX w. była już ona organizowana na podstawie uchwał poszczególnych dzielnicowych rad narodowych, przyjmując dla tej aktywności górnolotną nazwę samorząd mieszkańców miast. Zadaniem komitetów była realizacja społecznych celów i zadań w miejscu zamieszkania oraz współdziałanie z władzami dzielnicy. Dość szybko ta forma organizacji uległa znacznej biurokratyzacji. Komitety powoływały własne

7. M. Woźny, Władze Wrocławia, „Kalendarz Wrocławski”, 1985, s. 137. (Po ustąpieniu S. Apoznańskiego z funkcji prezydenta, S. Skąpski zajął jego miejsce i pełnił urząd aż do połowy 1990 r.).

8. R. Nowakowski, Kobiety we władzach miejskich Wrocławia i województwa wrocławskiego w latach 1954-1988-1990, [w:] Kobiety na "zakręcie" 1933-1989, pod red. E. Chabros, E. Klarman, Wrocław 2014, s. 88.

9. J. Regulski, Samorządna Polska, Warszawa 2005, s. 27. 10. Dz. U. 1983, Nr 41, poz. 185.

11. Alicja Lewandowska, b. radna Rady Miejskiej Wrocławia, wspomina, iż swego czasu "na moim osiedlu komitet osiedlowy zaskarżył decyzję Wojewody Wrocławskiego do Naczelnego Sądu Administracyjnego" (relacja z 13.12.2016 r. w posiadaniu R. Nowakowskiego). komisje, zespoły, sekcje, tworzyły plany i wytyczne pracy, eliminując spontaniczność i dowolność działań. Koresponduje to po części z opinią prof. Regulskiego: „Celem [władz - R.N.] było związanie obywateli z miejscem pracy, aby w ten sposób uzależnić ich od systemu władzy i wyeliminować możliwość niezależnych zachowań. Nie istniały formy organizacji społecznej wokół miejsca zamieszkania. Rządząca partia obawiała się bowiem spontanicznych i niekontrolowanych inicjatyw lokalnych, opierających się na wspólnocie interesów mieszkańców"9. Poważna zmiana w pozycji tych komitetów poczyniona została ustawą o systemie rad narodowych i samorządzie terytorialnym z 1983 r. ${ }^{10}$. Dała ona ustawowe przesłanki do tworzenia i funkcjonowania samorządu mieszkańców. Ustawa zapewniła środki finansowe w postaci funduszu wydzielanego m.in. przez rady dzielnicowe, możliwość wnoszenia sprzeciwu wobec rad narodowych i ich organów w przypadku nieuwzględnienia opinii samorządu mieszkańców, a także prawo uczestniczenia w postępowaniu administracyjnym ${ }^{11}$.

Nowy status miasta w 1957 r. zmienił nie tylko model zarządzania miastem, w którym zarówno władze miejskie, jak i dzielnicowe otrzymały szereg nowych uprawnień, ale przyczynił się do jakościowej zmiany w sferze organizowania, planowania i wykonywania szeregu zadań. Zmiany te należy odbierać jako udaną inicjatywę władz miasta w ramach dość krępującego swobodę działania ustroju rad narodowych. Jednak już w połowie lat siedemdziesiątych XX w. nastąpiły kolejne zmiany, mniej już korzystne dla miasta.

Miasto. Pamięć i Przyszłość 1 (2016) ISSN 2543-621X 
W ramach rozwiązań przyjętych 1 stycznia 1957 r., Wrocław i jego władze dotrwały do czerwca 1975 r. Istotne zmiany nastąpiły w latach 1972-1975, kiedy to przejściowo przywrócono urząd Prezydenta Wrocławia przy jednoczesnym przeorganizowaniu pozycji i roli prezydium RNmW. Do 1973 r. w skład tego organu wchodzili przewodniczący, jego zastępcy, sekretarz oraz tzw. niestali członkowie. W latach 1973-1975 w wyniku ponownego utworzenia jednoosobowego terenowego organu administracji państwowej kompetencje wykonawczo-zarządzające powierzono prezydentowi Wrocławia. Samo prezydium, tworzone już wyłącznie przez przewodniczącego, jego zastępców oraz przewodniczących stałych komisji rady, stało się obok stałych komisji rady organem wewnętrznym rady narodowej. Analogiczne zmiany zaszły na szczeblu dzielnic, w których kompetencje wykonawcze powierzono naczelnikom dzielnic.

Zasadnicze przekształcenia nastąpiły jednak w połowie 1975 r., co było konsekwencją dwustopniowej reformy terytorialnej kraju ery gierkowskiej. Rozporządzeniem Rady Ministrów z dnia 30 maja 1975 r. powołano jednostkę administracyjną stopnia wojewódzkiego dla miasta i województwa. Utworzono wówczas wspólną Radę Narodową Województwa Wrocławskiego i miasta Wrocławia (RNWWm.W) przez połączenie RNm.W i WRN. Stało się to 1 czerwca 1975 r., i zakończyło tym samym okres działania władz miejskich Wrocławia. Miasto jako jednostka terytorialna wraz z ustrojem organów administracyjnych przestało istnieć. Decyzja władz

Miasto. Pamięć i Przyszłość 1 (2016) ISSN 2543-621X

37 centralnych, podjęta arbitralnie bez konsultacji z mieszkańcami oraz władzami administracyjno-partyjnymi szczebla miejskiego, przekreśliła nie tylko dotychczasową rangę miasta jako jednostki stopnia wojewódzkiego, lecz przede wszystkim jego podmiotowość. Skorzystały na tym dzielnice. Wrocław stał się luźną federacją pięciu dzielnic. Dodatkowo wchodziły one w skład województwa złożonego z 15 miast i 42 gmin, a ich rady narodowe działały na podobnych zasadach, będąc radami stopnia podstawowego. Tak więc działania dzielnic nie były koordynowane na szczeblu miasta, co dało asumpt do powstania i rozwoju partykularyzmu dzielnicowego. Nie było bowiem instancji, która komasowałaby plany rozwojowe, zagadnienia budżetowo-finansowe, kompetencyjne w skali ogólnomiejskiej etc. Eksperyment polegający na utworzeniu i funkcjonowaniu wielkiej aglomeracji miejskiej bez spójnego systemu zarządzania i władz dbających o harmonijny rozwój miasta okazał się niekorzystnym rozwiązaniem ${ }^{12}$.

Z początkiem lat osiemdziesiątych XX w. rozpoczęła się dyskusja na temat odejścia od przyjętych rozwiązań i przywrócenia odrębnych władz miasta. Na fali dyskusji dotyczącej przywrócenia rangi i pozycji miasta jednoznaczne stanowisko zajęła sama RNWWm.W, która rozpoczęła lobbing w Warszawie w sprawie zmiany status quo. Batalia o zmianę modelu zarządzania miastem toczyła się już jednak w nowych warunkach ustrojowych: zmienił się podział administracyjny kraju, w którym zlikwidowano powiaty. Zmieniły się również liczba i kształt dotychczasowych

12. Zob. R. Nowakowski, Odbudowa administracji miejskiej Wrocławia w latach 1984-1990, [w: 25 lat samorzadu Wrocławia, pod red. R. Nowakowskiego, G. Straucholda, W. Sulei, Wrocław 2015. 
województw. Działania oddolne i naciski na władze centralne przyniosły oczekiwane skutki. Z początkiem 1983 r. Rada Państwa podjęła decyzję o przywróceniu samodzielności administracyjnej miasta. Ustawą z dnia 20 lipca 1983 r. Sejm PRL restytuował - podobnie jak w kilku innych największych miastach, m.in. w Poznaniu - władze miejskie Wrocławia, tj. Miejską Radę Narodową i urząd Prezydenta, ale w randze pierwszej instancji. Bez zmian pozostawiono dzielnicowe rady narodowe i ich organy wykonawcze, tj. naczelników wraz z podległym im aparatem, tj. urzędami dzielnicowymi, które w wielu sprawach były władzami tego samego szczebla. Mimo że było to rozwiązanie kuriozalne - i wywołało spore problemy w zarządzaniu miastem - decyzja władz państwowych została odebrana przychylnie. Ostateczne zagadnienie podziału uprawnień i obowiązków, a także zadań i kompetencji pomiędzy nowo powstałą Wojewódzką Radą Narodową i Miejską Radą Narodową oraz pięcioma Dzielnicowymi Radami Narodowymi pozostawiono do rozwiązania samym zainteresowanym. Dokonać się to miało po przeprowadzeniu wyborów do rad narodowych i ukonstytuowaniu się władz poszczególnych szczebli, co stało się w połowie czerwca 1984 r. Decyzja ta była fatalna w skutkach, gdyż zapoczątkowała kilkuletnie spory o podział zadań i kompetencji między dzielnicami, miastem a województwem.

13. Archiwum Państwowe we Wrocławiu (dalej: APW), Protokół nr 22/85 z posiedzenia Prezydium Wojewódzkiej Rady Narodowej we Wrocławiu z 20 XII 1985 r. Protokoły z posiedzeń Prezydium Wojewódzkiej Rady Narodowej 1985, syg. 16, s. 2. Stanowisko Prezydium Miejskiej Rady Narodowej z 13 XI 1985 r. w sprawie organizacji i funkcjonowania miejskich organów władzy i administracji państwowej we Wrocławiu stanowi załącznik do protokołu, s. 6-7, oraz załącznik nr 2 do stanowiska - Struktura organizacyjna Urzędu Miejskiego we Wrocławiu w zakresie działania oraz zatrudnienia w Wydziałach według stanu na dzień 1985 X 31 r.
Zadania i kompetencje miasto przejmowało dwuetapowo: w połowie 1984 r. i w połowie 1987 r. W pierwszym okresie odbyło się to głównie kosztem uprawnień dzielnicowych rad narodowych. W drugim zadania i kompetencje przekazano MRN przede wszystkim z poziomu wojewódzkiego, choć sprawy ostatecznego umocowania kompetencyjnego dzielnic, instancyjności w postępowaniu administracyjnym czy kwestie nadzoru były elementem dyskusji pomiędzy władzami miasta a województwem.

Mimo negatywnych konsekwencji rozmycia kompetencji i odpowiedzialności między dzielnice, miasto i województwo aż do zakończenia działania rad narodowych w 1990 r. nie udało się ostatnim nomenklaturowym władzom Wrocławia przejąć z poziomu województwa wielu zadań i kompetencji, niezbędnych do efektywnego zarządzania miastem. Przy zasadzie domniemania kompetencji rad dzielnicowych i koordynacyjnej roli WRN, a przede wszystkim przy braku własnego budżetu, który był ujmowany w strukturze budżetu województwa, władze miasta miały mocno ograniczone pole działania. Było to również widoczne na przykładzie tworzenia administracji ogólnomiejskiej, tj. Urzędu Miejskiego, czy w poszukiwaniu siedziby dla władz miejskich. W pierwszym przypadku aż połowę etatów nowo utworzonego urzędu, tj. 188, stanowiły etaty pozyskane z przesunięcia z pięciu urzędów dzielnicowych ${ }^{13}$. Na siedzibę władz miejskich oddano budynki przy Nowym Targu oraz gmach przy ul. G. Zapolskiej. Co interesujące, a warte przypomnienia, w nowym

Miasto. Pamięć i Przyszłość 1 (2016) ISSN 2543-621X 
ratuszu, siedzibie władz Wrocławia, od 1952 r. zlokalizowano Prezydia Dzielnicowych Rad Narodowych Starego Miasta i Fabrycznej, a także Urząd Skarbowy Wrocław - Stare Miasto. Po reformie administracyjnej w 1975 r. utworzono tam Urzędy Dzielnicowe dla Starego Miasta (Sukiennice 9) oraz dla Fabrycznej (Sukiennice 10). Na pierwszym piętrze mieściły się zaś kasy Prezydium Miejskiej Rady Narodowej i sale wydziału finansowego. Obrady Miejskiej Rady Narodowej odbywały się w budynku przy Nowym Targu w sali $215^{14}$.

Jak należy więc ocenić prawie 40-letni okres podziału administracyjnego Wrocławia na dzielnice? Bez wątpienia cieniem kładzie się tu dziewięcioletni okres (w latach 1975-1984) działania efemerycznej jednostki wspólnej dla województwa i miasta. Nie tylko wpłynął on negatywnie na wizerunek i prestiż Wrocławia, ale też uwolnił tendencje odśrodkowe na poziomie dzielnic. Przekreślono tym samym zrównoważony rozwój miasta. Skuteczne działania w latach osiemdziesiątych XX w. przyniosły przywrócenie odrębności administracyjnej Wrocławia. Proces budowy kompetencji aparatu administracyjnego, a przede wszystkim władz miasta był procesem wciąż niedokończonym. Miejska Rada Narodowa i Prezydent Wrocławia musieli kohabitować z dzielnicowymi radami narodowymi i ich naczelnikami przy braku wyraźnego podziału zadań i kompetencji. Mimo przywrócenia władz miejskich w połowie 1984 r. i likwidacji dzielnic w 1991 r., a także zabiegów władz i partnerów społecznych ten nierówny rozwój miasta jest

Miasto. Pamięć i Przyszłość 1 (2016) ISSN 2543-621X 39 wciąż widoczny. Negatywną ocenę tych rozwiązań podziela Stanisław Apoznański, prezydent miasta w latach 1984-1985 i radny Rady Miejskiej Wrocławia w latach 1994-2002: „Po wyborach w czerwcu 1984 r. [...] zacząłem tworzyć miejską administrację od podstaw. Wtedy prezydent nie miał takich kompetencji jak teraz. Dzisiaj prezydent jest prawdziwym gospodarzem. Ma do dyspozycji konkretny budżet i razem z Radą Miejską decyduje o jego wykorzystaniu. Ja nie miałem takich możliwości [...]. Miasto było podzielone na pięć dzielnic miejskich. Każda z dzielnic dbała o swoje interesy, nie patrząc na całość. Wcześniej próbował to czynić wojewoda, gdyż miasta jako bytu odrębnego wówczas nie było. Przywrócenie władzy w mieście nie rozwiązało tych problemów. Ówczesne prawo administracyjne przewidywało istnienie dwóch instancji, a mój urząd znalazł się między nimi [Urzędami Dzielnicowymi a Urzędem Wojewódzkim - R.N.]. To powodowało problemy w zarządzaniu. W części zagadnień byłem pierwszą instancją, w innych zaś drugą nad dzielnicami. Sprawy te do końca nie zostały uregulowane. Wrocław był za mało znaczącym przypadkiem, żeby w skali całego kraju zmienić prawo. Należało się do tego jakoś dopasować. Mimo iż naczelnicy dzielnic nie podlegali mi formalnie, stworzyłem Kolegium Prezydenckie. Zapraszałem na nie naczelników i próbowałem koordynować rozwiązanie miejskich problemów"15.

Przepychanki na linii miasto - województwo trwały aż do zakończenia działania rad

14. H. Okólska, 150 lat wrocławskiego Nowego Ratusza, Wrocław 2014, s. 31-32.

15. S. Apoznański, [w:] Rozmowy o dwudziestoleciu. Wspomnienia radnych Rady Miejskiej Wrocławia z lat 1990-2010, Wrocław 2010, s. 59 . 
narodowych w 1990 r. Aż do wyborów samorządowych z końcem maja 1990 r. struktura miasta była mocno rozproszona. Obok pięciu urzędów dzielnicowych z własnymi zadaniami i budżetami, ratusz był de facto urzędem z dość ograniczoną rolą w wyniku „okopania” się władz wojewódzkich i dużej autonomii, jak na warunki PRL-owskiego centralizmu, administracji dzielnic, które były jednostkami podziału terytorialnego stopnia podstawowego.

\section{Wrocław osiedlowy ${ }^{16}$}

Restytucja samorządności w Polsce w 1990 r. otworzyła nowy etap w rozwoju Wrocławia, uwalniając dyskusję nad ustrojem dużych miast, w której uwzględniono negatywne doświadczenia z tzw. rozbicia dzielnicowego.

Kwestie przyszłego modelu zarządzania gminą, jej wewnętrznego ustroju, struktury i terytorialnej organizacji powróciły na przełomie 1989/90 r. za sprawą prac przygotowawczych legislatywy.

Senacki projekt ustawy o samorządzie terytorialnym, przyjęty prawie jednogłośnie przez Sejm 8 marca 1990 r., wykluczał możliwość wprowadzenia regulacji dotyczących obligatoryjnych związków w dużych miastach. Jednocześnie jednak Sejm pod wpływem krytyki wprowadził dodatkowy artykuł mówiący, iż w miastach, w których istniały 1 stycznia 1990 r. wyodrębnione administracyjnie dzielnice, mogą one uzyskać status gminy. Decyzję w tej sprawie podejmuje Prezes Rady

16. Szerzej zob.: R. Nowakowski, Spory o ustrój i model samorzadu miejskiego, [w:] "Gra o miasto". W 20 rocznice odbudowy samorząu w Polsce, pod red. R. Nowakowskiego, Wrocław 2010.

17. Art. 5 ust. 4. - Dz. U. 1990, Nr 16, poz. 95.

18. R. Bubnicki, Jaka ordynacja wyborcza do organów samorzadu, „Wieczór Wrocławia” z 23/25 || 1990.

19. Wrocław będzie gmina??, "Gazeta Robotnicza” z 13 III 1990.
Ministrów po zasięgnięciu opinii zainteresowanych środowisk. Dzielnice stanowiące gminy tworzą obligatoryjny związek gmin, którego zadania i ustrój określają odrębna ustawa17 i art. 38 przewidujący odrębność ustroju gmin, które wykonują zadania o szczególnym charakterze, co określają właściwe ustawy. W szczególności dotyczy to gmin uzdrowiskowych. Zapisami tymi zapoczątkowano gorącą dyskusję nad przyszłym ustrojem i organizacją dużych miast. Jej temperaturę podgrzewały zabiegi i walka Warszawy wokół nadania dotychczasowym siedmiu dzielnicom statusu związku gminnego. Kontrowersji nie brakowało również we Wrocławiu. Wrocławski Komitet Obywatelski "Solidarność" (WKO „S"), który skupiał w dużej mierze opozycyjnych działaczy solidarnościowych i szykował się do przejęcia władzy w mieście. Już 21 lutego 1990 r. wystosował list do sejmowej Komisji Prac Ustawodawczych. Przedstawił propozycje do opublikowanego senackiego projektu, w którym opowiedział się za jednolitym organizmem samorządowym z jedną radą miasta. Ewentualny podział na dzielnice i osiedla mógłby zostać dokonany poprzez nową radę miejską ${ }^{18}$. Za modelem jednej, silnej władzy ogólnomiejskiej o dużych kompetencjach opowiadała się również część sił politycznych w mieście, które uważały, iż rozbicie miasta spowoduje rozproszenie sił i środków, a przede wszystkim sprzyja powstawaniu partykularnych interesów społecznych ${ }^{19}$. Wyraz temu stanowisku dały: Ruch Alternatywnego Myślenia, Polska Partia Zielonych, UPR, Polski Związek Katolicko-Społeczny, podczas spotkania na temat „Problemy miasta Wrocławia w świetle

Miasto. Pamięć i Przyszłość 1 (2016) ISSN 2543-621X 
projektu nowej ustawy o samorządzie terytorialnym", zorganizowanego w połowie marca $1990 \mathrm{r}$. przez przewodniczącego kończącej żywot Miejskiej Rady Narodowej prof. Jana Pławnickiego ${ }^{20}$.

Za odmiennym scenariuszem opowiadały się trzy spośród pięciu dzielnic Wrocławia ${ }^{21}$. Model obligatoryjnego związku gmin lansowany był przez Dzielnicowe Rady Narodowe z Krzyków, Fabrycznej i Psiego Pola22. Prezydium DRN Krzyki argumentowało, iż utrzymanie dotychczasowych dzielnic jako podstawowych organów samorządu terytorialnego, połączonych w obligatoryjny związek gmin, wyposażonych w znaczne kompetencje, zagwarantuje sprawność funkcjonowania miasta. Na szczeblu miejskim zaś pozostawione powinny być funkcje o znaczeniu ogólnomiejskim. Ponadto 60 radnych [miejskich - R.N.] nie będzie w stanie zapewnić reprezentacji wszystkim mieszkańcom na szczeblu gminy²3. Przewodniczący Prezydium DRN Psie Pole występował w obawie przed marginalizacją peryferyjnej dzielnicy miasta: „jedyne, czym się kieruję, to troska o rozwój dzielnic peryferyjnych. Jedna gmina to ponowna centralizacja władzy na szczeblu miasta, za którą optuje Stare Miasto i Śródmieście, bo nic nie mają do stracenia, gdyż są od dawna ucywilizowane. Ponownie Psie Pole funkcjonować będzie na marginesie molocha. Reprezentacja 1 radnego na 10 tys. mieszkańców to fikcja samorządności"24. Były przewodniczący Wrocławskiego Komitetu Obywatelskiego, a następnie członek WKO "S" prof. F. Połomski wystąpienia te

Miasto. Pamięć i Przyszłość 1 (2016) ISSN 2543-621X 41 nazwał dążeniami dotychczasowej nomenklatury do zachowania starych struktur, które nie sprawdziły się w działaniu. Stąd potrzebny jest jeden sprawny samorząd ${ }^{25}$. Postulatowi utrzymania tradycyjnego podziału Wrocławia WKO "S" przeciwstawiał nowy efektywny model zarządzania miastem w oparciu o samorząd osiedlowy26. Dziewiątego maja 1990 r. tzw. Grupa Robocza WKO „S", którą kierował Bogdan Zdrojewski, przedstawiła gotową koncepcję przyszłego podziału miasta na osiedla. Zakładała ona, iż na bazie dotychczasowych 41 osiedlowych komitetów obywatelskich utworzy się rady osiedli. Automatyczne przekształcenie miało zostać usankcjonowane uchwałą Rady Miejskiej tuż po wyborach samorządowych ${ }^{27}$. Program wyborczy WKO "S" nie przesądzał jednak do końca o ostatecznym kształcie jednostek samorządowych, choć prezentował rozwiązanie, które stało się rzeczywistością rok później. „Obecnie dzielnice są sztuczne. Nowe dzielnice wyodrębnione w oparciu o istniejące więzi funkcjonalne i przestrzenne winny być mniejsze i liczniejsze. Utworzone w nich

20. O przyszłości Wrocławia, „Słowo Polskie” z 14 III 1990.

21. A. Szumski, Przyszłe zarzadzanie miastem, "Słowo Polskie” z 5 III 1990.

22. J.S., Dzielnice, osiedla, sołectwa, „Wspólnota” z 28.04/5 V 1990.

23. Radni z Krzyków chca podziału na dzielnice, "Gazeta Robotnicza” z 2 V 1990.

24. M. Głowacki, Bez dzielnicowego samorzadu trudno o harmonijny rozwój miasta. Rozmowa z przewodniczacym DRN Psie Pole Remigiuszem Wirq, "Słowo Polskie” z 24 IV 1990.

25. Wrocław dzielnicowy czy w jednym kawałku?, „Wieczór Wrocławia" z 4 IV1990.

26. Sztuka podejmowania decyzji. Rozmowa z Andrzejem Olszewskim i Zenonem Wysłouchem z WKO "S", "Słowo Polskie" z 27 IV 1990.

27. BZNiO, DzDżS, Statusu osiedlowych komitetów obywatelskich "Solidarność" po wyborach do Rady Miejskiej miasta Wrocławia wraz z projektem Statutu Samorzadu Mieszkańców osiedla (jako 7-stronicowym załącznikiem). Wrocław 9 maj 1990 r., syg. (6457). 
rady niższego szczebla, czy to dzielnicowe, czy osiedlowe, dadzą lepszą możliwość reprezentowania interesów środowiskowych"28. Przed wyborami we Wrocławiu nie sprecyzowano więc konkretnej koncepcji podziału miasta.

Spory i kontrowersje ujawnione wokół statutu i ustroju dużych miast nie zakończyły się bynajmniej przed wyborami samorządowymi. Druga i zarazem właściwa faza dyskusji rozpoczęła się wraz z wyborem nowych samorządów największych miast. Toczyła się już ona wyłącznie w oparciu o przepisy zawarte w ustawie z 8 marca 1990 r. o samorządzie terytorialnym.

Przepisy ustawy o samorządzie terytorialnym wprowadziły pojęcie samorządowych jednostek pomocniczych. Zastąpiły one w pewnym sensie dotychczasową konstrukcję tzw. samorządów mieszkańców tworzonych w gminach wiejskich w formie sołectw, a w miastach w formie osiedli29, które rozwiązano z końcem 1990 r. Zerwanie z pojęciem samorządu mieszkańców wsi i osiedla miejskiego na rzecz pojęcia jednostki pomocniczej gminy wynikało z zasadniczych różnic. O ile pierwsza kategoria była formą organizacji mniejszej wspólnoty lokalnej przewidzianej do realizacji celów społecznych - co gwarantowała ustawa o systemie rad narodowych i samorządu terytorialnego z 1983 r., o tyle w nowych warunkach ustrojowych mieszkańców gminy uznano za

28. BWNSUWr, PDiŻBS - Biuletyn Solidarnościowego Porozumienia Wyborczego, Wrocław maj 1990 r., s. 26.

29. K. Trafas, Polskie modele jednostek pomocniczych, [w:] Vademecum radnego dzielnicy, red. K. Trafas, Kraków 1996, s. 99.

30. B. Zawadzka, Samorządowa organizacja mieszkańców w miastach, [w:] Państwo, demokracja, samorząd. Księga jubileuszowa na 65-lecie prof. E. Zielińskiego, pr. zb., Warszawa 1999, s. 154-155; Więź wspólnoty, „Wspólnota” z 14 VII 1990.

31. Dz. U. 1990, Nr 16, poz. 95. podstawową wspólnotę lokalną. Stąd gminy stały się fundamentem samorządności, jednostki pomocnicze zaś istotnym wsparciem w zarządzaniu jednostką terytorialną. Równolegle tworzyć miały ramy więzi i społecznej integracji poniżej tego szczebla - w lokalnej mikroskali pełnić funkcję pośrednika między organami miasta a mieszkańcami i zapewnić tym ostatnim szansę rzeczywistego udziału w samorządzie ${ }^{30}$.

Zagadnienie dotyczące tworzenia, powoływania i funkcjonowania gminnych jednostek pomocniczych ustawodawca scedował na gminne organy uchwałodawcze. Zasady i ramy ich funkcjonowania miały być określone w statutach gminnych, które stanowić miały również o ustroju gminy. W miastach powyżej 300 tys. mieszkańców statuty gminne podlegały uzgodnieniu z prezesem Rady Ministrów ${ }^{31}$. Z tego powodu prace nad nowymi "konstytucjami" miast prowadzone były równocześnie z propozycjami nowego podziału. Rozpoczęły się tuż po wyborach z końca maja 1990 r. i zakończyły w pierwszej połowie 1991 r. Mimo dość szybkiego tempa prac kwestia ustroju miast okazała się zagadnieniem trudnym i problematycznym.

We Wrocławiu już z końcem lipca 1990 r. podczas dyskusji nad projektem statutu miasta, pojawiły się kontrowersje wokół przyszłego podziału samorządowego miasta. Wielość opinii, uwag oraz kierunek dyskusji ujawniły brak jakiejkolwiek spójnej koncepcji. Rada Miasta utworzyła więc doraźną 10-osobową Komisję Samorządową pod kierunkiem Henryka Mikorskiego, która nie zdołała jednak wypracować satysfakcjonującej propozycji.

Miasto. Pamięć i Przyszłość 1 (2016) ISSN 2543-621X 
Z początkiem września po rozwiązaniu tej komisji przyszły podział miasta scedowano na Komisję Statutową pod kierunkiem Jerzego Barańskiego. Już w połowie października 1990 r., podczas omawiania statutu miasta, zaprezentowano podział na pomocnicze jednostki w formie osiedli. Uszczegółowienie i korektę projektu przekazano zespołowi eksperckiemu pod kierunkiem radnego prof. Andrzeja Jagielskiego. 10 listopada 1990 r. zespół ekspertów przedstawił pierwszy projekt podziału miasta, zakładający utworzenie ok. 50 jednostek. Punktem wyjścia były: zasięg i liczba (ponad 40) osiedlowych komitetów obywatelskich, modyfikacja terytoriów i liczby dotychczasowych 90 samorządów mieszkańców, tj. starych komitetów osiedlowych, topografia terenu, demografia etc.32. Ostatecznie po kolejnych konsultacjach społecznych, które odbyły się pod koniec 1990 r., oraz zebraniu wniosków i opinii w okręgach wyborczych opracowano dwa konkurencyjne projekty: projekt radnego A. Jagielskiego zakładający podział miasta na 44 samorządowe jednostki pomocnicze i projekt radnego Wacława Wdowiaka utworzenia 26-36 jednostek. Podczas posiedzenia Rady Miejskiej 6 lutego 1991 r. w drugim czytaniu przyjęto pierwszą wersję, którą przedstawiono następnie mieszkańcom do ostatecznego zaopiniowania33. W „Dzienniku Dolnośląskim” z 5 marca 1991 r. zamieszczono zmieniony projekt podziału miasta przewidujący utworzenie 46 osiedli34. W ostatecznym natomiast kształcie, po uwzględnieniu opinii kilku komitetów obywatelskich, metodą dzielenia i łączenia Rada Miejska Wrocławia 20 marca 1991 r. przyjęła podział miasta na 47 osiedlowych

Miasto. Pamięć i Przyszłość 1 (2016) ISSN 2543-621X 43 jednostek pomocniczych Wrocławia ${ }^{35}$. Osiedla różniły się pod względem powierzchni - pisał A. Jagielski - od 124 ha do 4331 ha oraz liczbą mieszkańców od 42 do 400 tys. Taka nieco kontrastowa delimitacja osiedli była głównie rezultatem preferencji integracyjnych oraz aktywności i żądań społeczności lokalnych ${ }^{36}$. Dotyczyło to także małych peryferyjnych osiedli, takich jak np. Lipa Piotrowska, Świniary, Rędzin, mających po mnniej więcej tysiąc mieszkańców, które domagały się własnych osiedli.

Do końca pierwszego kwartału 1991 r. dokonano wyboru modelu organizacyjnego gmin. Zasadniczymi kwestiami były umocowanie kompetencyjne nowych jednostek samorządowych w strukturze ustrojowej miast oraz sposób ich finansowania. Sprawy te wywołały jednak ogromną polemikę, gdyż oczekiwania rozminęły się z praktyką. Krótko mówiąc, nowe jednostki pomocnicze otrzymały zaledwie uprawnienia opiniodawcze z pominięciem prerogatyw decyzyjnych i wykonawczych. Osłabienie pozycji kompetencyjnej gmin ustawą z 17 maja 1990 r. sprawiło, iż władze miejskie niechętnie decydowały się na dodatkowe uszczuplenia swojego władztwa. Z kolei negatywne doświadczenia z poprzedniego ustroju powodowały, iż dominował postulat centralizacji władzy na szczeblu ogólnomiejskim. Jak pisał wrocławski

32. Archiwum Zakładowe Urzędu Miejskiego Wrocławia (dalej: AZUMW), Protokoły z Sesji Rady Miejskiej Wrocławia nr 13/90 z dnia 10 listopada $1990 \mathrm{r}$.

33. Uchwała nr XVIII/100/91 Rady Miejskiej Wrocławia z dnia 6 lutego 1991 r. ws. projektu podziału Wrocławia na osiedla.

34. Projekt podziału Wrocławia na pomocnicze jednostki samorzadowe wraz ze Statutem Wrocławia, „Dziennik Dolnośląski” z 5 III 1991.

35. Uchwała nr XX/110/91 Rady Miejskiej Wrocławia z dnia 20 marca 1991 r. ws. podziału Wrocławia na osiedla.

36. A. Jagielski, Mieszkańcy powojennego Wrocławia. Zarys rozwoju demograficznego i zmian demografii miasta, Rocznik Wrocławski nr 1 z 1993 r., s. 208. 
radny A. Lenkiewicz: „zarząd miasta niechętnie przejawiał względy do jakiegokolwiek uszczuplenia jego władzy na rzecz jednostek pomocniczych"137.

We Wrocławiu pozycję ustrojową 47 osiedlowych jednostek pomocniczych regulowały statut miasta z 6 lutego 1991 r. ${ }^{38}$ oraz generalny (do czasu zakończenia wyborów) dla wszystkich jednostek tzw. ramowy status osiedli z 24 lipca 1991 r. ${ }^{39}$. Sprawy finansowe regulowała osobna uchwała z 24 lipca 1991 r.40.

Wrocławskie kalkulacje przewidywały, iż do połowy 1991 r. większość osiedli będzie mieć wybrane swoje rady bądź zarządy. Wrocławska ordynacja wyborcza do samorządu osiedlowego nie przewidywała bowiem obligatoryjnego wyboru rad osiedlowych. Ich ukonstytuowanie scedowano na mieszkańców osiedli. Pierwsze wybory odbyły się dopiero pod koniec czerwca 1991 r., i to w zaledwie 5 osiedlach: w Leśnicy, na Oporowie, w Żernikach, Kuźnikach i na Brochowie $^{41}$. W połowie listopada 1991 r. wybory

37. A. Lenkiewicz, (Zd)Rada (Na)gminna Wrocławia, Wrocław 1994, S. 25.

38. Uchwała nr XVIII/102/91 Rady Miejskiej Wrocławia z dnia 6 lutego 1991 r., ws. przyjęcia Statutu Wrocławia w brzmieniu uzgodnionym w URM w dniu 1 lutego 1991 r.

39. Uchwała nr XXVII/156/91 Rady Miejskiej Wrocławia z dnia 24 lipca 1991 r. - ramowy statut osiedla.

40. Uchwała nr XXVII/164/91 Rady Miejskiej Wrocławia z dnia 24 lipca 1991 r., ws. zasad podziału środków na działalność samorządowych jednostek pomocniczych.

41. Pierwsi rajcowie, „Wieczór Wrocławia” z 25 VII 1991.

42. Rzecznik prasowy Rady Miejskiej informuje, "Wieczór Wrocławia” z 14 XI 1991

43. Rzecznik Rady Miejskiej informuje, "Wieczór Wrocławia” z 26 V 1992; Lepiej mieszkać na osiedlu z głowa, "Gazeta Robotnicza” z 27 $\vee 1992$.

44. Większość osiedli ma już swoje rady, „Wieczór Wrocławia” z 13 VII 1993.

45. Uchwała nr LXIV/421/93 Rady Miejskiej Wrocławia z dnia 22 maja 1993 r. ws. nadania statutu osiedla. przeprowadzono w kolejnych 27 osiedlach ${ }^{42}$. W połowie maja 1992 r. rzecznik prasowy Rady Miejskiej informował, iż wyborów do rad dokonano już w 37 osiedlach ${ }^{43}$. Ostatnie wybory przeprowadzono w kwietniu 1993 r. W efekcie własne organy wybrały aż 43 osiedla. Jedynie mieszkańcy Lipy Piotrowskiej, Tarnogaju, Zakrzowa i Gądowa-Popowic Południa nie wybrali władz ${ }^{44}$. Z tego względu pod koniec maja 1993 r. Rada Miejska, sankcjonując nowy porządek prawny w osiedlach, nadała 43 statuty. Rady osiedli powołano w 32 jednostkach, w 11 przypadkach (Bieńkowice, Jagodno, Jerzmanowo-JarnołtówStrachowice, Klecina, Kowale, Muchobór Wielki, Pawłowice, Polanowice-Poświętne-Ligota, Sołtysowice, Świniary i Widawa) organem uchwałodawczym zaś było ogólne zebranie mieszkańców, a wykonawczy stanowił zarząd ${ }^{45}$. Relację z przygotowania i przebiegu wyborów prezentowała prasa lokalna. Trudno było znaleźć odpowiednią liczbę kandydatów na radnych. Niska była także (2\%) frekwencja wyborcza do samorządów osiedlowych, co nie zmieniło się praktycznie na przestrzeni ostatniego ćwierćwiecza.

\section{Kierunki i koncepcje reformy osiedli władz miejskich}

Pierwsze poważne dyskusje nad korektą podziału miasta na jednostki pomocnicze rozpoczęły się z początkiem III kadencji Rady Miejskiej Wrocławia (1998-2002). Zauważyć należy, iż w 1994 r., tj. od drugiej kadencji Rady Miejskiej Wrocławia, utworzono doraźną komisję ds. osiedli, która w kolejnych kadencjach tworzona była już jako stała komisja ds. osiedli (w obecnej VII kadencji

Miasto. Pamięć i Przyszłość 1 (2016) ISSN 2543-621X 
komisja partycypacji społecznej i osiedli), w której pracach tematem głównym była reforma osiedli.

Pierwsza poważna koncepcja reformy osiedli pojawiła się 19 lipca 1999 r. jako jeden z punktów posiedzenia Zarządu Miasta. Był to ogólny projekt zakładający zmniejszenie liczby osiedli przy jednoczesnym zwiększeniu ich kompetencji. Inicjatorem zmian byli przedstawiciele AWS we władzach miejskich, którzy w wyniku powyborczych targów z ekipą prezydenta Bogdana Zdrojewskiego otrzymali zagadnienie jednostek pomocniczych. Zajmował się nim członek Zarządu Miasta Grzegorz Oszast46, natomiast wypracować koncepcję miało Biuro Rozwoju Wrocławia. Już 7 września przedstawiło ono trzy warianty podziału administracyjnego miasta na dzielnice w liczbie 12-10-10, przy czym władze nie ukrywały, iż optują za wariantem pierwszym, tj. 12 dzielnic. W tym było tzW. Wielkomiejskie Centrum Wrocławia (WCW). Miejsce zlikwidowanych rad osiedli miały zająć rady dzielnic z większymi uprawnieniami i budżetami ${ }^{47}$.

Istotnym novum było wyodrębnienie terenów spod władz przyszłych zarządów dzielnicowych i oddanie ich pod bezpośredni zarząd rady gminy. Chodziło o tereny mające znaczenie dla wszystkich mieszkańców, jak: pola irygacyjne, tereny wodonośne, a także ścisłe centrum, tj. Stare Miasto, wskazane w projekcie WCW ${ }^{48}$. Projekt został poddany konsultacjom z radami osiedli. Główne uwagi dotyczyły wielkości i granic dzielnic, oddalenia radnego osiedla od mieszkańców, sztucznego wydzielenia WCW. Za utrzymaniem status quo

\section{Miasto. Pamięć i Przyszłość 1 (2016) ISSN 2543-621X}

45 opowiadali się również mieszkańcy ${ }^{49}$. ZZmiany są potrzebne. Radni w osiedlach są bliżej spraw mieszkańców, chcemy, aby mieli większy wpływ na to, co się dzieje, ale to wymaga reformy" - komentował wiceprezydent Stanisław Huskowski ${ }^{50}$. Brakowało również jednomyślności w tonie samego Zarządu Miasta, który 7 września 1999 r. przełożył dyskusję na kolejne posiedzenie. Projekt, który miał być przedstawiony Radzie Miejskiej do zatwierdzenia wraz z ordynacją wyborczą na rok przed końcem II kadencji rad osiedlowych, został jednak zarzucony. Brakło jednomyślności i politycznej woli wśród koalicjantów.

Aż do 2008 r. temat reformowania osiedli był sporadycznie podnoszony $w$ dyskursie publicznym. W czerwcu 2008 r. władze miejskie przedstawiły propozycję nowego podziału miasta na jednostki pomocnicze. Ponownie miały być to dzielnice w liczbie 15-20 z własnymi radami, ale i delegowanymi przez prezydenta urzędnikami zatrudnionymi w Biurach Obsługi Klienta na poziomie każdej jednostki. Projekt - przedstawiony publicznie w połowie czerwca przez radnych z Komisji ds. osiedli Rady Miejskiej - przewidywał również pełne wynagrodzenie dla członków zarządów dzielnic. Szerzej o tym projekcie wspomina Marek Mutor,

46. R. Nowakowski, Rada Miejska, Zarzad Miasta i Prezydent, [w:] Anatomia sukcesu miasta. Wrocław i jego samorzad w latach 19902015, pr. zb. E. Czapiewski, A. Łoś, R. Nowakowski, Wrocław 2016, s. $24,83-84$.

47. P. Przybylski, Co to znaczy decentralizacja, „Wieczór Wrocławia” z 1999.

48. KG, Podział dzielnicowy, "Gazeta Wyborcza/Dziennik Dolnośląski" z 8 IX 1999.

49. Na marginesie reformy dzielnicowej. Pawłowice nie chca do Zawidawia, „Wieczór Wrocławia” z 14 IX 1999 (plus sonda: Rady małe czy duże?).

50. K. Górowicz, Jak Wam się podoba?, "Gazeta Wyborcza/Gazeta Dolnośląska" z 7 IX 1999. 
radny Klubu Rafała Dutkiewicza, jeden z pomysłodawców koncepcji (obok Szymona Hotały) ${ }^{51}$.

Sceptycyzmu nie kryli przede wszystkim radni osiedli. W założeniach upatrywali próbę zerwania ze społecznym charakterem rad, a przede wszystkim ich upolitycznieniem, poprzez udział w nich kandydatów wspieranych przez partie i ugrupowania polityczne. W dyskusji nad zaprezentowaną koncepcją udział wzięli lokalni politycy i naukowcy. Prof. Leon Kieres, były wrocławski radny, a ówczesny senator $\mathrm{PO}$, przestrzegał przed autonomią jednostek, by nie rozbudzać separatystycznych dążeń, i przypomniał idę subsydiarności, która tak jak w przypadku samorządów powinna być realizowana na poziomie jednostek pomocniczych. Również Aldona Młyńczak, posłanka PO i była radna osiedlowa i miejska, uznała pomysł za nieprzemyślany i nawiązujący do rozwiązań sprzed 50 lat. Politolog z Uniwersytetu Wrocławskiego dr Andrzej Ferens mówił z kolei: „Likwidacja osiedli może spowodować, że władza oddali się od obywatela. Ważne jest, aby władza miała kontakt z mieszkańcami, a z tym nie jest najlepiej. Świadczy o tym niska frekwencja wyborcza. Pozytywem może być większy wpływ na kształt polityki ogólnomiejskiej, jeśli dzielnice otrzymają większe kompetencje niż osiedla"52. Ambiwalentnej postawy nie ukrywał poseł PiS, były wiceprezydent Wrocławia Dawid Jackiewicz: „W Radach Osiedli jest tyle polityki, ile pieniędzy, czyli niewiele. Samorządowcy osiedlowi to typowi społecznicy, którzy za symboliczne wynagrodzenie poświęcają swoim osiedlom mnóstwo czasu. Pomysł, aby wzmocnić

51. Ponieważ koncepcja ta została dogłębnie zaprezentowana w niniejszym tomie w osobnej relacji M. Mutora, Autorzy zrezygnowali z jej omawiania.

52. Władza bliżej ludu, „Polska Gazeta Wrocławska” z 24 VI 2008.

53. Nowy podziat, nowe problemy?, "Polska Gazeta Wrocławska” z 27 VI 2008. kompetencje RO i wyposażyć je w większe środki finansowe jest godny rozważenia. [...] Widać jednak jasno zagrożenia płynące z proponowanego podziału. [...] Warunkiem koniecznym do sprawnego funkcjonowania RO jest ich ochrona przed nadmiernym upolitycznieniem"53. Mimo próby przeforsowania reformy przed zaplanowanymi wyborami do rad osiedli w marcu 2009 r. sprawa ponownie poległa z przyczyn politycznych. Radni z klubu PiS nie zgadzali się na wdrażanie tak rewolucyjnych zmian tuż przed wyborami. Natomiast radni z koalicyjnego klubu PO oponowali ze względu na ambicje prezydenta, który od marca 2008 r. rozpoczął formowanie Stowarzyszenia Dolny Śląsk XXI w obawie przed przejęciem rad przez ludzi prezydenta i członków stowarzyszenia. Ze względu na brak jednomyślności wśród klubów radnych jesienią od projektu odstąpił również R. Dutkiewicz.

Po półrocznej przerwie na początku 2009 r. ponowną dyskusję nad reformą osiedli zainicjowało Stowarzyszenie Dolny Śląsk XXI. Zaproponowało ono przygotowanie reformy do $2010 \mathrm{r}$. tak, by wybory do rad odbyły się równolegle z wyborami samorządowymi. Rozważano utworzenie od 15 do 20 dzielnic, przy czym wskazywano na preferowaną liczbę 16 jednostek zamieszkiwanych przez ok. 30-50 tys. mieszkańców. Lansowano ideę wyborów "obywatelskich” w jednomandatowych okręgach wyborczych zamieszkiwanych przez 1500-2000 mieszkańców. Opowiadano się za klarownym podziałem kompetencji między radą a zarządem dzielnicy. Ta pierwsza miała uchwalać najważniejsze dokumenty, zatwierdzać plany finansowe, listę

Miasto. Pamięć i Przyszłość 1 (2016) ISSN 2543-621X 
lokalnych zadań. Miała również kontrolować zarząd.

W projekcie uwzględniono także realny wpływ na budżet miejski. Dzielnice miały mieć możliwość planowania pieniędzy np. na drogi osiedlowe, skwery, zagospodarowanie podwórek, a zadania te miały być zapisane w budżecie. Nowatorskim pomysłem była natomiast propozycja udziału przewodniczących rad osiedli w sesjach Rady Miejskiej z możliwością udzielania im głosu ${ }^{54}$. Planowane zmiany wywołały burzę i przed wyborami samorządowymi 2010 r. temat został ponownie wyciszony.

\section{Osiedla w praktyce}

Podział kompetencji i finansów był nieustannie krytykowany przez radnych rad osiedli. We Wrocławiu dotacje na działalność osiedli wynosiły zaledwie 0,2\% budżetu gminy w skali roku. W monografii dotyczącej Oporowa odnotowano: „Ważnym wydarzeniem dla pięciotysięcznego osiedla było utworzenie Rady Osiedla. Jednak w praktyce okazało się, że możliwości wywalczenia czegokolwiek przez Radę Osiedla u władz miasta były znacznie ograniczone. Tylko dzięki uporowi Zarządu Osiedla udało się załatwić kilka ważnych spraw"55. Z początkiem marca 1992 r. przedstawiciele 9 Rad Osiedlowych oznajmili, iż „współpraca z miastem rzadko wykracza poza deklaracje składane przez urzędników i niektórych radnych. Opinie rad nie są uwzględniane, więc zaczynają się organizować, by mieć lepszą pozycję nacisku na Radę Miejską"56. Tak rozpoczął się proces tworzenia struktury poziomej, tj. federacji osiedli w proteście przeciw nagminnemu

Miasto. Pamięć i Przyszłość 1 (2016) ISSN 2543-621X 47 łamaniu przez władze miejskie ich statutów ${ }^{57}$. Konkretnych kształtów inicjatywa nabrała przed wyborami samorządowymi w 1994 r. Na bazie federacji powołano komitet wyborczy pod nazwą Samorządowa Koalicja Osiedli, skupiający 34 z 47 osiedli58. Przedstawiciele osiedli w wyborach 1994 r. zdobyli 5 mandatów i powołali własny klub radnych Samorządowa Koalicja Nasze Osiedle (SKNO) w Radzie Miejskiej Wrocławia. W wyborach do rad osiedli 1996 r. z ramienia SKNO weszło do rad ok. 450 radnych (prawie połowa wszystkich radnych)!

Wraz z pojawieniem się AWS na ogólnopolskiej i miejskiej scenie politycznej, w strukturach tego ruchu znaleźli się również członkowie SKNO, a pełnomocnik koalicji Ryszard Bubień został pełnomocnikiem ds. samorządu w AWS. Tym sposobem kandydaci na radnych wystawieni przez AWS szli do wyborów z programem, w którym kwestia reformy rad osiedlowych była istotnym punktem ${ }^{59}$. W kadencji 1998-2002 Klub Radnych AWS, w ramach którego obok ZCH-N, SK-L, PCHD, Ruchu Stu, Rodziny Polskiej znaczą siłę stanowiła Samorządowa Koalicja Osiedlowa, zgłosił projekt reformy rad osiedlowych. Przewidywał on zwiększenie kompetencji oraz zmniejszenie liczby rad. Miało się to odbyć ewolucyjnie poprzez samoistne łączenie się osiedli w większe

54. M. Kozioł, Jak 48 wrocławskich osiedli zamieni się w 16 dzielnic, „Polska Gazeta Wrocławska" http://www.serwis.brzdac.olkusz.pl165-serwis-higiena.investmap.pl/post/53310 (dostęp: 06.09.2016).

55. M. Czapliński, S. Rospond, Z dziejów Oporowa, Wrocław 2002, S. 74.

56. Osiedla sfederowane?, „Słowo Polskie” z 20 III 1992.

57. Rady łącza się. Za komitet założycielski Federacji Rad Osiedli Julian Rodziewicz RO Karłowice-Różanka i Sylwester Szkudlarek RO Ołbin, "Gazeta Robotnicza" z 5 X 1993.

58. Koalicja osiedlowa, "Gazeta Robotnicza” z 16 XII 1993.

59. "Wrocław 2000" do podziału?, "Wieczór Wrocławia” z 13 III 1998. 
jednostki. W kadencji 2002-2006 podjęto natomiast działania zmierzające do opracowania WPI - Wieloletnich Planów Inwestycyjnych, w ramach których osiedla będą wydatkowały środki na osiedlowe inwestycje w ramach budżetu miasta ${ }^{60}$. W latach 2006-2010 prezydent powołał zespół ds. opracowania zmian w statucie rad osiedlowych. Udział w nich brali przedstawiciele rad osiedlowych. Jednak wiele propozycji zmian, które sformułowali przedstawiciele rad, nie zostało uwzględnionych w ostatecznych rozwiązaniach.

Według M. Lampczaka, przewodniczącego rady osiedla Stare Miasto, rady osiedli miały stosunkowo dużo uprawnień w pierwszym okresie działalności. W każdej kolejnej kadencji uprawnienia te były ograniczane, co dokonywało się w sposób formalny poprzez poprawki do statutu lub nieliczenie się z uchwałami rad. Rolę rad ograniczono jedynie do opiniowania spraw, którymi faktycznie powinny się zajmować, a aktywność społeczną ograniczono nadmierną biurokracją poprzez utworzenie specjalnego biura do obsługi rad osiedlowych. Lekceważenie przejawiały władze wykonawcze. Również Rada Miejska nie traktowała po partnersku rad

60. W. Kilian, Działalność samorzadu Wrocławia, [w:] Sytuacja i rola wielkiego miasta w procesie transformacji, Studium porównawcze rozwoju ekonomicznego i procesów społecznych na przykładzie Wrocławia i Lipska - kontynuacje, pod red. Z. Kurcza i Z. Morawskiego, Wrocław 2003, s. 18, 22.

61. Cyt za.: Zob. Z. Kurcz, Samorzad Wrocławia, [w:] Sytuacja i rola wielkiego miasta w procesie transformacji, Studium porównawcze rozwoju ekonomicznego i procesów społecznych na przykładzie Wrocławia i Lipska - kontynuacje drugie, pod red. Z. Kurcza i Z. Morawskiego, Wrocław 2009, s. 22-24.

62. R. Nowakowski, Edward Czapiewski, Między nauka i polityką, [w: Nauka-Samorząd-Polityka. Księga Jubileuszowa dedykowana prof. Edwardowi Czapiewskiemu w 40-lecie pracy zawodowej i dydaktycznej, pod red. R. Nowakowskiego i G. Straucholda, Wrocław 2014, s. $19-23$. osiedli61. W pierwszych latach od powołania jednostek pomocniczych stałym elementem były spotkania "Prezydium" Rady Miejskiej Wrocławia z przewodniczącymi rad osiedli. Po kilku latach zaniechano tego modelu współpracy.

Ważnym momentem, w którym działacze rad osiedli dali ponownie o sobie znać, były pierwsze bezpośrednie wybory prezydenta miasta w 2002 r. Wśród 11 komitetów wyborczych było również Wrocławskie Forum Samorządowe, reprezentowane głównie przez osiedlowych działaczy i społeczników, idących również z hasłem reformy wrocławskich osiedli. I choć w myborach do rady WFS zdobyło prawie 4,0\% głosów, a kandydat na prezydenta niecałe 2,0\%, to był to kolejny sygnał płynący z "dołu” o potrzebie dokończenia reformy, której domagali się sami zainteresowani ${ }^{62}$.

Warto przypomnieć, iż wielu radnych miejskich wywodzi się wprost z rad osiedlowych, m.in. Aldona Młyńczak, Krzysztof Kilarski, Marek Mutor, Aleksander Garczarek, Katarzyna Obara-Kowalska, Rafał Czepil, Alina Barczewska, Tadeusz Bereżański, Michał Jasiński, Mirosław Iwanicki, Ryszard Bubień, Henryk Macała, Radosław Pietrzyk, Urszula Wanat, Piotr Kuczyński czy Ireneusz Józwiak oraz Sebastian Lorenc. Kilku radnych miejskich było z nimi związanych, np. Ewa Rzewuska. Jak pisze trafnie Wojciech Morozek, „[...] wiele osób biorących udział w pracach kolejnych rad osiedla i zarządu osiedla rozpoczynało w ten sposób swoją przygodę z samorządem terytorialnym, a następnie kontynuowało ją we wrocławskich strukturach samorządu terytorialnego, w szczególności

Miasto. Pamięć i Przyszłość 1 (2016) ISSN 2543-621X 
jako radni Rady Miejskiej"63. Wielu z nich kontynuowało działalność na wyższych stanowiskach publicznych.

25 lat, które minęły od powołania samorządowych jednostek pomocniczych, pozwala na zebranie krytycznych opinii na temat ich funkcjonowania. Analizując materiały komisji ds. osiedli Rady Miejskiej Wrocławia, stwierdzić należy, iż dochodziło do ciągłych prób secesji, zmiany nazw, rewizji granic osiedli. W kilku przypadkach próby te okazały się skuteczne ${ }^{64}$. Liczne były spory personalne w łonie samych rad, co niekiedy prowadziło do paraliżu ich funkcjonowania ${ }^{65}$. Po wieloletnich próbach w 2006 r. doszło do podziału osiedla Wojszyce-Ołtaszyn i powstania dwóch osobnych osiedli: Wojszyc i Ołtaszyna66. Tym samym liczba jednostek pomocniczych we Wrocławiu wzrosła z 47 do 48.

\section{Jaka przyszłość rad osiedlowych? Propozycje i rekomendacje}

Wiele o osiedlach mówi przede wszystkim sama frekwencja myborcza, która jest rażąco niska. Oznacza to, że ogromna większość wyborców nie widzi sensu w startowaniu do rad osiedli ani tym bardziej głosowania w tych wyborach. Można mówić o swoistej kwadraturze koła. Rady osiedli mogą niewiele załatwić, więc wyborcy ignorują akt wyborczy. Ta bezradność uwidacznia się często w braku odpowiedniej liczby kandydatów na radnych. Albo jest ich akurat tylu, ile miejsc, albo ich brakuje. W pierwszym przypadku nie przeprowadza się aktu wyborczego, lecz powołuje się radę (11 przypadków w 2013 r.). W drugim odwołuje się wybory i nie powołuje się organów osiedla. Tak było m.in. podczas ostatnich wyborów

Miasto. Pamięć i Przyszłość 1 (2016) ISSN 2543-621X w 2013 r. na osiedlu Przedmieście Oławskie. Zdarza się również wygaszanie mandatów radnym osiedlowym, którzy rezygnują w trakcie kadencji ze społecznej aktywności i przestają uczestniczyć w sesjach rady. W świetle przytaczanych faktów pod rozwagę należy poddać pomysł powiązania wyborów do rad osiedlowych z wyborami do Rady Miejskiej, co niewątpliwie poprawiłoby frekwencję, a także ustanowienia niewielkich diet dla radnych.

\section{Tab. 2. Frekwencja w wyborach do rad} osiedli - średnia w \%

\begin{tabular}{|c|c|c|}
\hline Kadencja & Rok wyborczy & Średnia \\
\hline I & $1991 / 2$ & 2,0 \\
\hline II & 1996 & 7,7 \\
\hline III & 2000 & 8,5 \\
\hline IV & 2005 & 4,5 \\
\hline V & 2009 & 4,0 \\
\hline VI & 2013 & 4,0 \\
\hline
\end{tabular}

Źródło: Opracowanie własne na podstawie Obwieszczeń Miejskiego Komisarza Wyborczego.

63. W. Morozek, Ustrój Miasta Wrocławia w latach 1990-2010, [w:] 20 lat samorzadu terytorialnego w II i III Rzeczypospolitej. I Wydziałowa konferencja Kół Naukowych Wydziału Prawa, Administracji i Ekonomii Uniwersytetu Wrocławskiego, red. J. Korczak, Wrocław 2010, s. 435.

64. Np. Uchwała nr XXXVII/521/97 Rady Miejskiej Wrocławia z dnia 25 kwietnia 1997 r. w sprawie zmiany nazwy osiedla Jerzmanowo-Jarnołtów-Strachowice (dodano 4. człon -Osiniec) czy też Uchwała nr LII/812/98 Rady Miejskiej Wrocławia z dnia 5 czerwca 1998 r. w sprawie zmiany uchwały nr XX/110/91 Rady Miejskiej Wrocławia z dnia 20 marca 1991 r. w sprawie podziału Wrocławia na osiedla (zmiana nazwy z "Popowice Pd-Gądów" na "Gądów-Popowice $\mathrm{Pd}^{\prime \prime}$ ).

65. Przykład rady osiedla Osobowice-Rędzin, która po wyborach 2013 r. rozpadła się w wyniku konfliktu personalnego co w konsekwencji doprowadziło do przeprowadzenia wyborów uzupełniających w maju 2015 r. http://www.gazetawroclawska. pl/artykul/3757505,w-maju-wybory-na-dwoch-wroclawskich-osiedlach-bo-radnym-nie-chcialo-sie-pracowac,id,t.html (dostęp: 9.09.2016).

66. Uchwała nr XLVII/3060/06 Rady Miejskiej Wrocławia z dnia 16 lutego 2006 r. w sprawie podziału Osiedla Wojszyce-Ołtaszyn. 
Pojawia się pytanie: co trzeba uczynić w celu zmiany status quo? Trzeba przyznać, że nasz parlament postąpił właściwie, nie narzucając dużym miastom (prócz Warszawy) koncepcji dzielnic. Specyfika dużych aglomeracji jest swoista i trudno narzucać jednolitą koncepcję dla Wrocławia, Krakowa, Poznania czy jeszcze bardziej zróżnicowanego Trójmiasta. Ustawa z marca 1990 r. dała tego typu miastom możliwości i od nowych władz miejskich zależało, jaki kształt ustrojowy nadadzą swojemu miastu.

We Wrocławiu pojawiły się różne koncepcje, począwszy od Wrocławskiego Komitetu Obywatelskiego „S", który przewidywał zamianę 41 osiedlowych komitetów obywatelskich na rady osiedlowe. Rada Miejska I kadencji po stosunkowo krótkiej, chociaż burzliwej dyskusji przyjęła ostateczny projekt 47 osiedli. Na zasadzie kompromisu Rada przyjęła, że rady osiedla otrzymają kompetencje opiniodawcze, natomiast zabrakło decyzyjnych i wykonawczych. W następnych kadencjach planowano ten projekt ulepszać. Zabrakło jednak woli zmian i rady osiedli stały się swoistym zakładnikiem władzy miejskiej ${ }^{67}$. Od III kadencji rozpoczęły się dyskusje nad zmianą podziału administracyjnego osiedli (zmniejszenie ich liczby) oraz dodaniem im kompetencji wykonawczych. Zarówno dyskusja w 1999 r., jak i kolejne z lat 2008 i 2009 nie przyniosły rezultatów. Podzieliły polityków samorządowych spory o podział administracyjny i zakres kompetencji. Pojawiały się także dodatkowe interpretacje, jak przywoływana opinia L. Kieresa, aby nie rozbudzać separatystycznych dążeń. Tymczsem „reforma osiedlowa może stać się istotnym czynnikiem budowy dobrego kapitału ludzkiego [...]. Decentralizacja władzy nie jest chorobą czy wynaturzeniem. Jest koniecznością dla zbudowania aktywnego kapitału ludzkiego, tak potrzebnego dla lepszego funkcjonowania władzy i zapewnienia skutecznej kontroli społecznej68.

\section{Zakończenie}

Ustawa o samorządzie terytorialnym - likwidująca rady narodowe, jej organy, a także samorząd osiedlowy mieszkańców - ustanowiła, iż mieszkańcy z mocy prawa stanowią wspólnotę samorządową. Gmina zgodnie z art. 164.1 Konstytucji RP z 1997 r. stanowi podstawową jednostkę samorządu terytorialnego. Jednostki pomocnicze gminy są strukturami tworzonymi poniżej szczebla gminnego. Powoływanie ich uzależniono od swobodnego uznania rady gminy (fakultatywność) bez ustawowego określenia jej charakteru prawnego. Ich status majątkowy, finansowy, zakres działania i kompetencje uzależniono również od samej rady gminy.

Jednostka pomocnicza w gminie, czy to w formie sołectwa, osiedla, dzielnicy, a od noweli z września 1995 r. w innej równoprawnej formie, jest wyłącznie jednostką wewnętrznego podziału gminy. Mimo iż posiada demokratycznie wybrane przedstawicielstwo, tj. radę jako organ uchwałodawczy i zarząd wybierany w wyborach pośrednich, kierowany przez przewodniczącego, które reprezentuje jedynie część mieszkańców gminy zamieszkałych na wydzielonym terytorium gminy, nie posiadaja odrębnej od gminy osobowości prawnej. Jej działalność, określona wyłącznie statutem 
zawierającym zasady tworzenia, łączenia oraz ich znoszenia, prowadzona jest wyłącznie w ramach osobowości prawnej gminy. Fakt ten znacznie osłabia znaczenie art. 39 ust 4 ustawy, który uprawnia radę gminy do upoważnienia przewodniczącego organu wykonawczego jednostki pomocniczej do załatwiania indywidualnych spraw z zakresu administracji publicznej. Jak pisze Barbara Zawadzka, sformułowanie to należy traktować na "wyrost”. Trudno sobie wyobrazić, w jaki sposób jednostka pomocnicza nieposiadająca osobowości prawnej mogłaby stać się przedmiotem wydającym decyzje administracyjne, funkcjonujące w obrocie prawnym i ponosić za nie prawną odpowiedzialność. Trudno sobie wręcz wyobrazić, w jaki sposób społeczny organ wykonawczy jednostki, niedysponujący fachowym aparatem, mógłby „załatwić” sprawy wymagające znajomości prawa ${ }^{69}$. Wyposażenie przewodniczącego organu wykonawczego jednostki pomocniczej w uprawnienia władcze przez organ stanowiący gminy nie znajduje również potwierdzenia w 25-letniej historii funkcjonowania osiedli we Wrocławiu.

Podsumowując genezę podziału miast na jednostki pomocnicze, stwierdzić należy, iż na przyjętym modelu zaciążyły uwarunkowania minionej epoki (podział dzielnicowy), a także niechęć władz miejskich do dzielenia się władzą z „terenem”. Skromne były również możliwości prawne. Zauważyć więc należy, iż ustawodawca marginalnie potraktował zagadnienie decentralizacji władzy samorządowej w dużych miastach. Przewidywało ono jedynie dwa skrajne rozwiązania: z jednej strony układ dzielnice-gminy (model stolicy), z drugiej budowę jednostek pomocniczych w formie osiedli bądź dzielnic.

„Decentralizacja” uprawnień na niższy pomocniczy szczebel samorządności traktowana była dwojako: jako usprawnienie modelu zarządzania dużą jednostką miejską oraz próba organizowania społeczeństwa obywatelskiego na poziomie mikrospołecznym. Rzeczywistość prawno-ustrojowa znacznie pokrzyżowała te zamierzenia. Ograniczone kompetencyjnie gminy odreagowały powściągliwością w przekazywaniu zadań i kompetencji na niższe szczeble. W rezultacie samorządność osiedli okazała się fasadowa. We Wrocławiu Rada Miejska dość szybko ustanowiła diety i apanaże dla niektórych działaczy niższego szczebla, choć zakładano, iż prace te wykonywane będą społecznie. Tak jak na szczeblu centralnym, również na szczeblu gminnym triumfował centralizm. Frekwencja wyborcza była tego namacalnym dowodem i do dziś sięga zaledwie kilku procent. Wady przyjętych rozwiązań upatrywano w finansach i kompetencjach jednostek pomocniczych.

Rada Miejska Wrocławia jako pierwsza w Polsce powołała rady osiedli. Również jako pierwsza uchwaliła dla nich statut. Od tamtej pory dokonano 11 razy zmian w uchwale z 1991 r. regulującej funkcjonowanie jednostek pomocniczych.

We Wrocławiu zastosowano odgórny scenariusz tworzenia osiedli, w którym pominięto całkowicie kryterium ciągłości historycznej. Niestety, mimo ćwierćwiecza działania rad osiedlowych 1991-2016 prowizorka okazała się po raz kolejny
Miasto. Pamięć i Przyszłość 1 (2016) ISSN 2543-621X

51
69. B. Zawadzka, op. cit., s. 158. 
rozwiązaniem bardzo trwałym. Dlatego podjęcie dyskusji nad nowym kształtem ustrojowym osiedli uważamy za niezwykle ważne dla przyszłego kształtu naszej demokracji lokalnej. Trafnie podkreśla zaniechania w tym obszarze były prezydent Wrocławia Bogdan Zdrojewski, który po latach zauważa niedoskonałości rozwiązań przyjętych w czasach jego urzędowania: „Dzisiaj rad jest prawie 50, są ubezwłasnowolnione, bez pieniędzy, bez inicjatywy, a powinny być kuźnią talentów młodych samorządowców i partnerem dla władz Wrocławia (bo takiego prezydent Dutkiewicz nie ma). Jedynie Stare Miasto należało uznać za »dystrykt« zarządzany wprost z ratusza"70, co wzmacnia m.in. utworzenie w 2014 r. Parku Kulturowego "Stare Miasto”.

\footnotetext{
Edward Czapiewski prof. dr hab., absolwent historii na Wydziale Filozoficzno-Historycznym Uniwersytetu Wrocławskiego. W latach 1974-2006 r. pracownik naukowy Instytutu Historycznego UWr. Od 2006 r. pracuje w Dolnośląskiej Szkole Wyższej w Instytucie Bezpieczeństwa i Spraw Międzynarodowych, gdzie kieruje Zakładem Prawa i Bezpieczeństwa Międzynarodowego. Zajmuje sie badaniem historii myśli politycznej, historiq Rosji i stosunkami polsko-rosyjskimi. Autor ponad 100 publikacji, w tym współautor podręcznika akademickiego: Historia powszechna. Wiek XX. PWN, Warszawa 2010.
}

Tematem istotnym do rozwiązania w obecnej i przyszłej kadencji samorządu Wrocławia powinna stać się rzeczywista reforma osiedlowych jednostek pomocniczych i realizacja zapisów Strategii Wrocław w perspektywie 2020 Plus, m.in. pilotażowe przetestowanie nowatorskich rozwiązań na jednym z osiedli, a także wdrażanie rozwiązań takich jak np. Laboratoria Obywatelskie, zainicjowanych w ramach Wrocławskiego Budżetu Obywatelskiego 2015. Ćwierćwiecze rad osiedlowych, a także prace nad nową strategią miasta są odpowiednim momentem, aby zainicjować dyskusję wokół przyszłości rad osiedlowych, a przede wszystkim miasta.

Rafał Nowakowski historyk, politolog, absolwent Uniwersytetu Wrocławskiego. Zawodowo zwiq̨zany z administracja publiczna, naukowo z Dolnośląska Szkoła Wyższą. Współpracownik Ośrodka „Pamięći i Przyszłość”. Autor ponad 30 publikacji naukowych dotyczacych m.in. miasta i samorzadu Wrocławia, współpracy polsko-saksońskiej. Jest autorem plansz tematycznych w Centrum Historii Zajezdnia we Wrocławiu. Współautor publikacji pt. „Anatomia sukcesu miasta. Wrocław i jego samorząd w latach 1990-2015", Wrocław 2016. Zastępca red. nacz. i sekretarz Rady Naukowej rocznika "Miasto. Pamięć i Przyszłość".
70. B. Maciejewska, Wrocław moja miłość. A najbardziej lubię Odrę, "Gazeta Wyborcza" [Wrocław] z 15 || 2014. http://wroclaw. wyborcza.pl/wroclaw/1,35771,15462882,Zdrojewski_Wroclaw_ moja_milosc_A_najbardziej_lubie.html\#ixzz4JTcqMjEr (dostęp: 06.09.2016).
Miasto. Pamięć i Przyszłość 1 (2016) ISSN 2543-621X 


\section{Bibliografia:}

\section{Źródła}

\section{Archiwalne}

Archiwum Państwowe we Wrocławiu (dalej:

APW), Protokół nr 22/85 z posiedzenia Prezydium Wojewódzkiej Rady Narodowej we Wrocławiu z 20 XII 1985 r., [w:] Protokoły z posiedzeń Prezydium Wojewódzkiej Rady Narodowej z 13 XI 1985 r. w sprawie organizacji i funkcjonowania miejskich organów władzy i administracji państwowej we Wrocławiu stanowi załącznik do protokołu, s. 6-7, oraz załącznik nr 2 do stanowiska - Struktura organizacyjna Urzędu Miejskiego we Wrocławiu w zakresie działania oraz zatrudnienia w Wydziałach według stanu na dzień 1985 × 31 r.

Archiwum Zakładowe Urzędu Miejskiego Wrocławia (dalej: AZ UMW), Protokoły z Sesji Rady Miejskiej Wrocławia nr 13/90 z dnia 10 listopada $1990 \mathrm{r}$.

\section{Biblioteczne}

Biblioteka Wydziału Nauk Społecznych Uniwersytetu Wrocławskiego

- Biuletyn Solidarnościowego Porozumienia Wyborczego, Wrocław 1990.

Biblioteka Zakładu Narodowego im. Ossolińskich we Wrocławiu

- Statusu osiedlowych komitetów obywatelskich "Solidarność" po wyborach do Rady Miejskiej miasta Wrocławia wraz z projektem Statutu Samorządu Mieszkańców osiedla, Wrocław 9 maja 1990.

\section{Akty prawne}

\section{Ustawy}

Ustawa z dnia 11 września 1944 r. o organizacji i zakresie działania rad narodowych (Dz.U. 1944, Nr

5, poz. 22).

Ustawa z dnia 20 marca 1950 r. o terenowych organach jednolitej władzy państwowej (Dz.U. 1950, Nr 14, poz. 130).

Ustawa z dnia 25 września 1954 r. Ordynacja wyborcza do rad narodowych (Dz.U. 1954, Nr 43, poz. 193)

Ustawa z dnia 20 lipca 1983r. o systemie rad narodowych i samorządu terytorialnego (Dz.U. 1983, Nr 41, poz. 185).

Ustawa z dnia 8 marca 1990 r. o samorządzie terytorialnym (Dz.U. 1990, Nr 16, poz. 95).

\section{Pozostałe akty}

Dekret Rady Państwa z dnia 31 XII 1956 r. o wyłączeniu z województw miast: Krakowa, Poznania i Wrocławia oraz nadaniu miejskim radom narodowym tych miast uprawnień wojewódzkich rad narodowych (Dz.U. 1957, Nr 1, poz. 1).

Obwieszczenia Komisarzy Wyborczych o wynikach wyborów do poszczególnych rad narodowych m. Wrocławia za lata 1954-1988 Obwieszczenia Miejskiego Komisarza Wyborczego w sprawie ogłoszenia wyników wyborów do rad osiedli na terenie $\mathrm{m}$. Wrocławia w latach 1991-2013

\section{Uchwały Rady Miejskiej Wrocławia} Uchwała nr XVIII/100/91 Rady Miejskiej Wrocławia z dnia 6 lutego 1991 r. w sprawie Projektu podziału Wrocławia na osiedla. Uchwała nr XVIII/102/91 Rady Miejskiej Wrocławia z dnia 6 lutego 1991 r. w sprawie przyjęcia Statusu Wrocławia w brzmieniu uzgodnionym w URM w dniu 1 lutego 1991 r. Uchwała nr XX/110/91 Rady Miejskiej Wrocławia 
z dnia 20 marca 1991 r. w sprawie podziału Wrocławia na osiedla.

Uchwała nr XXVII/156/91 Rady Miejskiej Wrocławia z dnia 24 lipca 1991 r. - ramowy statut osiedla.

Uchwała nr XXVII/164/91 Rady Miejskiej Wrocławia z dnia 24 lipca 1991 r., w sprawie zasad podziału środków na działalność samorządowych jednostek pomocniczych.

Uchwała nr LXIV/421/93 Rady Miejskiej Wrocławia z dnia 22 maja 1993 r. w sprawie nadania statutu osiedla.

Uchwała nr XXXVII/521/97 Rady Miejskiej Wrocławia z dnia 25 kwietnia 1997 r. w sprawie zmiany nazwy osiedla Jerzmanowo-Jarnołtów-Strachowice Uchwała nr LII/812/98 Rady Miejskiej Wrocławia z dnia 5 czerwca 1998 r. w sprawie zmiany uchwały nr XX/110/91 Rady Miejskiej Wrocławia z dnia 20 marca 1991 r. w sprawie podziału Wrocławia na osiedla.

Uchwała nr XLVII/3060/06 Rady Miejskiej Wrocławia z dnia 16 lutego 2006 r. w sprawie podziału Osiedla Wojszyce-Ołtaszyn.

\section{Wywiady, rozmowy i wspomnienia}

Apoznański S. , Rozmowy o dwudziestoleciu. Wspomnienia radnych Rady Miejskiej Wroctawia z lat 1990-2010, Wrocław 2010

Lewandowska A., relacja z 13.12.2016 r. w posiadaniu R. Nowakowskiego.

Lenkiewicz A., (Zd)Rada (Na)gminna Wrocławia, Wrocław 1994

\section{Publikacje}

Czapliński M., Rospond S., Z dziejów Oporowa, Wrocław 2002

Okólska H., 150 lat wrocławskiego Nowego Ratusza, Wrocław 2014

Regulski J., Samorzadna Polska, Warszawa 2005 Rozwój terytorialny, Encyklopedia Wrocławia, red. J.

Harasimowicz, Wrocław 2006

Trafas K., Vademecum radnego dzielnicy, red. K.

Trafas, Kraków 1996

\section{Artykuły naukowe}

Czapiewski E., O samorządzie nie tylko krytycznie studium osobiste, [w:] 25 lat samorzadu Wrocławia, red. R. Nowakowski, G. Strauchold, W. Suleja, Wrocław 2015

Jagielski A., Mieszkańcy powojennego Wrocławia. Zarys rozwoju demograficznego i zmian demografii miasta, Rocznik Wrocławski nr 1, 1993

Kilian W., Sytuacja i rola wielkiego miasta w procesie transformacji, Studium porównawcze rozwoju ekonomicznego i procesów społecznych na przykładzie Wrocławia i Lipska - kontynuacje, pod red. Z. Kurcza, Z. Morawskiego, Wrocław 2003

Kurcz Z., Samorzad Wrocławia, [w:] Sytuacja i rola wielkiego miasta w procesie transformacji, Studium porównawcze rozwoju ekonomicznego i procesów społecznych na przykładzie Wrocławia i Lipska - kontynuacje drugie, pod red. Z. Kurcza, Z. Morawskiego, Wrocław 2009

Morozek K., Ustrój Miasta Wrocławia w latach 1990-2010, [w:] 20 lat samorzadu terytorialnego w II i III Rzeczpospolitej. I Wydziałowa konferencja Kót 
Naukowych Wydziału Prawa, Administracji i Ekonomii Uniwersytetu Wrocławskiego, red. J. Korczak, Wrocław 2010

Nowakowski R., Odbudowa administracji miejskiej Wrocławia w latach 1984-1990, [w:] 25 lat samorzadu Wrocławia, red. R. Nowakowski, G. Strauchold, W. Suleja, Wrocław 2015

Nowakowski R., Rada Miejska, Zarząd Miasta i Prezydent, [w:] Anatomia sukcesu miasta. Wrocław i jego samorzad w latach 1990-2015, pr. zb. E. Czapiewski, A. Łoś, R. Nowakowski, Wrocław 2016

Nowakowski R., Spory o ustrój i model samorzq̨du miejskiego, [W:] „Gra o miasto”. W 20. rocznice odbudowy samorzadu w Polsce, pod red. R. Nowakowskiego, Wrocław 2010

Nowakowski R., Jak W PRL zabiegano o zmianę rangi i pozycji administracyjnej Wrocławia, Kwartalnik "Pamięć i Przyszłość", nr 31 (1/16)

Nowakowski R., Kobiety w władzach miejskich Wrocławia i województwa wrocławskiego w latach 19541988-1990; [w:] Kobiety na „zakręcie” 1933-1989, pod red. E. Chabros, E. Klarman, Wrocław 2014 Nowakowski R., Edward Czapiewski. Między nauka i politykq, [w:] Nauka-Samorzq̨d-Polityka. Księga jubileuszowa dedykowana prof. Edwardowi Czapiewskiemu w 40-lecie pracy zawodowej i dydaktycznej, red. R. Nowakowskiego, G. Straucholda, Wrocław 2014

M. Woźny, Władze Wrocławia, Kalendarz Wrocławski 1985

Zawadzka B., Samorządowa organizacja mieszkańców w miastach; [w:] Państwo, demokracja, samorząd. Księga jubileuszowa na 65 - lecie prof. E. Zielińskiego, pr. zb., Warszawa 1999

\section{Prasa (chronologicznie)}

R. Bubnicki, Jaka ordynacja wyborcza do organów samorzadu, Wieczór Wrocławia z 23/25 || 1990
Wrocław będzie gminą?, Gazeta Robotnicza z 13 II 1990

O przyszłości Wrocławia, Słowo Polskie z 14 III 1990

A. Szumski, Przyszłe zarządzanie miastem, Słowo Polskie z 5 III 1990

J.S., Dzielnice, osiedla, sołectwa, Wspólnota z 28 IV/5 $\vee 1990$

Radni z Krzyków chca podziału na dzielnice, Gazeta Robotnicza z 2 V 1990

M. Głowacki, Bez dzielnicowego samorządu trudno o harmonijny rozwój miasta. Rozmowa z przewodniczacym DRN Psie Pole Remigiuszem Wira, Słowo Polskie z 24 IV 1990

Wrocław dzielnicowy czy w jednym kawałku?, Wieczór Wrocławia z 4 IV 1990

Sztuka podejmowania decyzji. Rozmowa z Andrzejem Olszewskim i Zenonem Wysłouchem z WKO „S", Słowo Polskie z 27 IV 1990

Projekt podziału Wrocławia na pomocnicze jednostki samorzadowe wraz ze Statutem Wrocławia, Dziennik Dolnośląski z 5 III 1991

Pierwsi rajcowie, Wieczór Wrocławia z 25 VII 1991 Rzecznik Prasowy Rady Miejskiej informuje, Wieczór Wrocławia z 14 IX 1991

Osiedla sfederowane?, Słowo Polskie z 20 III 1992 Lepiej mieszkać na osiedlu z głowa, Gazeta Robotnicza z 27 V 1992

Rady łącza się. Za komitetem założycielskim Federacji Rad Osiedli Julian Rodziewicz RO Karłowice-Różanka i Sylwester Szkudlarek RO Ołbin, Gazeta Robotnicza z $5 \times 1993$

Większość osiedli ma już swoje rady, Wieczór Wrocławia z 13 VII 1993

Koalicja osiedlowa, Gazeta Robotnicza z 16 XII 1993 "Wrocław 2000" do podziału, Wieczór Wrocławia z 13 III 1998

K.G., Podział dzielnicowy, Gazeta Wyborcza/Dziennik 
Dolnośląski z 8 IX 1999

K. Górowicz, Jak się Wam podoba?, Gazeta Wyborcza/Gazeta Dolnośląska z 7 IX 1999

Władza bliżej ludu, Polska Gazeta Wrocławska z 24

VI 2008

Nowy podziat, nowe problemy? Polska Gazeta Wrocławska z 27 VI 2008

M. Kozioł, Jak 48 wrocławskich osiedli zmieni się 16 dzielnic, Polska Gazeta Wrocławskahttp://www.serwis.brzdac.olkusz.pl-165-seriws-higiena.investmap. pl/post/53310 (dostęp: 06.09.2016).

Han, Tylko tych osiedli żal, "Gazeta Wrocławska Polska The Times", z 28 V 2010

Maciejewska B., Wrocław moja miłość. A najbardziej lubię Odrę, "Gazeta Wyborcza”, Wrocław z 15 I| 2014 http://wroclaw.wyborcza.pl/wroclaw/1,35771,15462882,Zdrojewski_Wroclaw_moja_ milosc_A_najbardziej_lubie.html\#ixzz4JTcqMjEr (dostęp: 06.09.2016). 